\title{
EPIDEMIC OF ACUTE RESPIRATORY DISEASE ASSOCIATED WITH ATYPICAL PNEUMONIA
}

\author{
BY LESTER BRESLOW 1
}

(From the Minnesota State Department of Health)

(Received for publication May 16, 1945)

Recently, the concept has developed that atypical pneumonia is merely an incident in what is usually a mild epidemic disease of the respiratory tract (1 to 6). A group of workers (3) summarize this idea:

"There is thus no sharp dividing line, other than roentgen evidence ... to differentiate cases of atypical pneumonia from cases of acute bronchitis resembling atypical pneumonia and from cases of other illness of the respiratory tract. . . . It seems probable that at least some of these minor illnesses may be milder infections of the same specific nature as atypical pneumonia. Proof of such a hypothesis depends on the demonstration of the causative agent."

Although numerous clinical and epidemiological descriptions ( 7 to 20 ) of the disease have appeared, etiological studies have been largely disappointing. A few of the cases, especially the more severe ones, have been demonstrated to be caused by ornithosis (21) and related agents, "Q" Fever (22) and lymphocytic choriomeningitis (23) but it was recently concluded that "a

\footnotetext{
1 Capt., M.C., A.U.S.
}

virus responsible for a large proportion of the cases of so-called virus pneumonia has not been satisfactorily established (24)."

The present communication deals with an explosive outbreak of respiratory disease, associated with atypical pneumonia, the etiology of which has been indicated to be the virus described by certain investigators (25).

The epidemic started in the only grade school of Kasson, a town in southeastern Minnesota, the population of which in 1940 was 1,230 people and spread into households of the school children. There were a total of 191 cases.

Table I shows the symptomatology of the disease, with cases divided arbitrarily into 3 groups: "severe," those with fever and bed-rest of more than 3 days; "moderate," those with fever and bed-rest of 3 days or less; and "mild," those without fever or whose temperature was not taken and bed-rest of 3 days or less. The "severe" cases of this outbreak would actually correspond to a fairly mild form of the disease as commonly described; none were hospitalized and only 29 per cent of the "severe" cases were in bed longer than 2 weeks, none longer than 3 weeks.

TABLE I

Symptomatology

\begin{tabular}{|c|c|c|c|c|c|c|c|c|}
\hline \multirow[b]{2}{*}{$\begin{array}{l}\text { No. of cases } \\
\text { Fever } \\
\text { Cough } \\
\text { Headache } \\
\text { Chest signs* } \\
\text { Sore throat } \\
\text { Coryza } \\
\text { Chest pain } \\
\text { Chilliness } \\
\text { G.I. symptoms } \\
\text { Days in bed } \\
1 \text { to } 3 \\
4 \text { to } 7 \\
8 \text { to } 14 \\
15 \text { to } 21\end{array}$} & \multicolumn{2}{|c|}{ "Severe" cases } & \multicolumn{2}{|c|}{ "Moderate" cases } & \multicolumn{2}{|c|}{ "Mild" cases } & \multicolumn{2}{|c|}{ Total cases } \\
\hline & $\begin{array}{c}\text { number } \\
31 \\
31 \\
31 \\
25 \\
12 \\
1 \\
1 \\
2 \\
6 \\
7 \\
\\
12 \\
10 \\
9\end{array}$ & $\begin{array}{c}\text { per cent } \\
100 \\
100 \\
100 \\
81 \\
39 \\
3 \\
3 \\
6 \\
19 \\
23 \\
\\
39 \\
32 \\
29\end{array}$ & $\begin{array}{c}\text { number } \\
47 \\
47 \\
37 \\
21 \\
10 \\
12 \\
1 \\
3 \\
6 \\
28\end{array}$ & $\begin{array}{c}\text { per cent } \\
100 \\
100 \\
79 \\
45 \\
\\
21 \\
26 \\
2 \\
6 \\
13 \\
60\end{array}$ & $\begin{array}{c}\text { number } \\
113 \\
74 \\
14 \\
17 \\
54 \\
1 \\
1 \\
5 \\
9\end{array}$ & $\begin{array}{c}\text { per cent } \\
100 \\
\\
65 \\
12 \\
15 \\
42 \\
1 \\
1 \\
4 \\
8\end{array}$ & $\begin{array}{c}\text { number } \\
191 \\
78 \\
142 \\
60 \\
12 \\
28 \\
67 \\
4 \\
10 \\
18 \\
37 \\
12 \\
10 \\
9\end{array}$ & $\begin{array}{c}\text { per cent } \\
100 \\
41 \\
74 \\
31 \\
6 \\
15 \\
35 \\
2 \\
5 \\
9 \\
19 \\
6 \\
5 \\
5\end{array}$ \\
\hline
\end{tabular}

* Only 26 patients examined during the acute stage of the illness. 
Of the 191 cases, 26 received chest examinations by a physician during the acute stage of the illness, these being the more seriously affected. Râles or dullness was noted in 12 of the 26 patients examined. The remainder of the cases did not of their own initative consult a physician, usually because of the mildness of the symptoms. Information concerning these was gathered through interview of the children and their parents during the acute stage or within a few days thereafter by a public health physician and public health nurses. Only 7 of the more severe cases were examined by $x$-ray, usually during early convalescence, and evidence of pneumonia was present in 5 .

TABLE II

Attack rate in grade school

\begin{tabular}{l|c|c|c}
\hline \hline & $\begin{array}{c}\text { Number } \\
\text { in room }\end{array}$ & $\begin{array}{c}\text { Number } \\
\text { ill }\end{array}$ & $\begin{array}{c}\text { Attack } \\
\text { rate }\end{array}$ \\
\hline & 23 & & per cent \\
First & 19 & 11 & 39 \\
Second & 19 & 10 & 58 \\
Third & 35 & 30 & 83 \\
Fourth and fifth & 36 & 22 & 61 \\
Fifth and sixth & 29 & 17 & 59 \\
Seventh & 25 & 18 & 72 \\
Eighth & 186 & 117 & 63 \\
\hline \multicolumn{1}{c|}{ Totals } & & 63 \\
\hline
\end{tabular}

Cough was the most common symptom, being present in 74 per cent of all cases; it was hacking in nature with little or no sputum and almost always persisted even in mild cases for 10 days or longer. This characteristic, persistent cough, to- gether with the relative infrequency of coryza, served in general to distinguish the "mild" cases of the outbreak clinically from the common cold and to identify them with the more severe cases. It will be noted that the incidence of coryza and sore throat was somewhat higher in the milder cases than in the severe, and the incidence of cough lower. Some of these milder cases may have been common colds or minor bacterial infections. However, no dividing line would be found clinically or temporally between the mild and severe cases of the epidemic.

The attack rates in the various rooms of the grade school are given in Table II. Of the 186 pupils in the school, 117 or 63 per cent were affected. The attack rates in the different rooms ranged from 39 to 86 per cent.

Household occurrence of the disease, by age groups, is shown in Tables III and IV. In the 94 households affected there were 329 persons exposed to secondary attack, considering the first case in each household as the primary attack: Ninety-seven or 29 per cent of the 329 persons exposed in households contracted the disease. However, most of these ( 56 of the 97 ) who did become ill were in the age group 5 to 14 years so that they were also exposed in school. Only 41 cases occurred among the 230 persons who were exposed in households but not in the school, giving a corrected secondary household attack rate of 18 per cent, to be compared with an attack rate of 63 per cent in the school. This difference may have been due to an age factor in

TABLE III

Age and sex distribution in primary and secondary cases

\begin{tabular}{|c|c|c|c|c|c|c|c|c|}
\hline & & \multicolumn{6}{|c|}{$\begin{array}{c}\text { Age } \\
\text { years }\end{array}$} & \multirow{2}{*}{ Totals } \\
\hline & & 0 to 4 & 5 to 9 & 10 to 14 & 15 to 19 & 20 or more & ?Age & \\
\hline \multirow[t]{2}{*}{ Primary cases: } & $\begin{array}{l}\text { Males } \\
\text { Females }\end{array}$ & $\begin{array}{l}1 \\
2\end{array}$ & $\begin{array}{l}15 \\
13\end{array}$ & $\begin{array}{l}24 \\
21\end{array}$ & $\begin{array}{l}4 \\
2\end{array}$ & $\begin{array}{r}2 \\
10\end{array}$ & $\begin{array}{l}\mathbf{0} \\
\mathbf{0}\end{array}$ & $\begin{array}{l}46 \\
48\end{array}$ \\
\hline & Totals & 3 & 28 & 45 & 6 & 12 & $\mathbf{0}$ & 94 \\
\hline \multirow[t]{2}{*}{ Secondary cases } & $\begin{array}{l}\text { Males } \\
\text { Females }\end{array}$ & $\begin{array}{l}3 \\
7\end{array}$ & $\begin{array}{l}13 \\
12\end{array}$ & $\begin{array}{l}13 \\
18\end{array}$ & $\begin{array}{l}2 \\
4\end{array}$ & $\begin{array}{r}9 \\
16\end{array}$ & $\begin{array}{l}\mathbf{0} \\
\mathbf{0}\end{array}$ & $\begin{array}{l}40 \\
57\end{array}$ \\
\hline & Totals & 10 & 25 & 31 & 6 & 25 & $\mathbf{0}$ & 97 \\
\hline \multirow[t]{2}{*}{ Total cases: } & $\begin{array}{l}\text { Males } \\
\text { Females }\end{array}$ & $\begin{array}{l}4 \\
9\end{array}$ & $\begin{array}{l}28 \\
25\end{array}$ & $\begin{array}{l}37 \\
39\end{array}$ & $\begin{array}{l}6 \\
6\end{array}$ & $\begin{array}{l}11 \\
26\end{array}$ & $\begin{array}{l}\mathbf{0} \\
\mathbf{0}\end{array}$ & $\begin{array}{r}86 \\
105\end{array}$ \\
\hline & Totals & 13 & 53 & 76 & 12 & 37 & $\mathbf{0}$ & 191 \\
\hline
\end{tabular}


TABLE IV

Secondary household attack rate*

\begin{tabular}{|c|c|c|c|c|c|c|c|}
\hline & & \multicolumn{6}{|c|}{ Age } \\
\hline & & 0 to 4 & 5 to 9 & 10 to 14 & 15 to 19 & 20 or more & ?Age \\
\hline \multirow[t]{2}{*}{ Males } & $\begin{array}{l}\text { Number exposed } \\
\text { Number of cases }\end{array}$ & $\begin{array}{l}8 \\
3\end{array}$ & $\begin{array}{l}17 \\
13\end{array}$ & $\begin{array}{l}22 \\
13\end{array}$ & $\begin{array}{l}9 \\
2\end{array}$ & $\begin{array}{r}93 \\
9\end{array}$ & $\begin{array}{l}8 \\
0\end{array}$ \\
\hline & $\begin{array}{l}\text { Attack rate } \\
\text { (A.R.) }\end{array}$ & 38 & 76 & 59 & 22 & 10 & 0 \\
\hline \multirow[t]{2}{*}{ Females } & $\begin{array}{l}\text { Number exposed } \\
\text { Number of cases }\end{array}$ & $\begin{array}{r}12 \\
7\end{array}$ & $\begin{array}{l}17 \\
12\end{array}$ & $\begin{array}{l}30 \\
18\end{array}$ & $\begin{array}{r}18 \\
4\end{array}$ & $\begin{array}{l}90 \\
16\end{array}$ & $\begin{array}{l}5 \\
0\end{array}$ \\
\hline & $\begin{array}{l}\text { Attack rate } \\
\text { (A.R.) }\end{array}$ & 58 & 71 & 60 & 22 & 18 & 0 \\
\hline \multirow[t]{2}{*}{ Totals } & $\begin{array}{l}\text { Number exposed } \\
\text { Number of cases }\end{array}$ & $\begin{array}{l}20 \\
10\end{array}$ & $\begin{array}{l}34 \\
25\end{array}$ & $\begin{array}{l}52 \\
31\end{array}$ & $\begin{array}{r}27 \\
6\end{array}$ & $\begin{array}{r}183 \\
25\end{array}$ & $\begin{array}{r}13 \\
0\end{array}$ \\
\hline & $\begin{array}{l}\text { Attack rate } \\
\text { (A.R.) }\end{array}$ & 50 & 73 & 60 & 22 & 14 & 0 \\
\hline
\end{tabular}

* Higher rates in younger age groups, especially the 5 to 9 and 10 to 14 groups, may reflect spread within the school rather than differential age attack rates.

susceptibility or to some unknown factor favoring spread in the school.

Although dates of onset were found to extend from September 1 to November 2, 1942, as shown in Table V, over 90 per cent of the cases occurred from September 29 to October 26, and this latter probably represented the true epidemic period. Nearly half of the cases appeared during the week October 6 to 12 . The outbreak may thus be said to have been explosive. In this respect, it differs from most of the epidemics which have been noted to extend over several months. One experience described (19) bears a close similarity to the present one.

The disease occurred indiscriminately among users of the one pasteurized milk supply, one public raw milk supply, and several private raw milk supplies, thereby eliminating milk from consideration as a possible source of infection. Water was excluded on similar grounds. Pigeons abounded in the school house and other nearby buildings. Investigation disclosed pigeons' droppings in the openings of the ventilating ducts into the school rooms, and 1 dead pigeon was found in the ventilating system. It was also stated that

live pigeons occasionally came through the ventilating system into the school rooms. In view of these facts, ornithosis was considered a possible etiology. Further investigation (detailed below) did not substantiate this hypothesis. The behavior of the disease in the households definitely suggested a respiratory mode of spread. The incubation period, estimated from the secondary occurrence in the household-exposed but nonschool-exposed group, was from 8 to 21 days.

Throat washings taken early in the course of the disease from several typical cases were inocu-

TABLE V

Dates of onset

Dates

September 1 to 7, 1942

September 8 to 14,1942

September 15 to 21,1942

September 22 to 28,1942

September 29 to Oct. 5, 1942

October 6 to 12,1942

October 13 to 19,1942

October 20 to 26, 1942

October 27 to Nov. 2, 1942

Total

Date not stated

Grand total

\begin{tabular}{cc}
$\begin{array}{c}\text { Number of } \\
\text { cases }\end{array}$ & $\begin{array}{c}\text { Per cent of } \\
\text { cases }\end{array}$ \\
2 & 1.2 \\
1 & 0.6 \\
3 & 1.8 \\
5 & 3.0 \\
28 & 16.6 \\
79 & 46.6 \\
32 & 18.9 \\
16 & 9.5 \\
3 & 1.8 \\
\hline 169 & 100.0
\end{tabular}


lated ${ }^{2}$ into mice. Pulmonary lesions occurred and some deaths after a few passages, but the responsible agent could not be differentiated from mouse pneumonia virus of Horsfall. It was not considered as having any etiological relation to the cases. Ten pairs of blood specimens showed no significant rise in titer between the acute-phase and convalescent specimens against influenza $\mathrm{A}$ (PR-8 strain) or influenza B (Lee strain).

The epidemiological evidence suggested ornithosis. Four pairs of blood specimens were submitted to Dr. K. F. Meyer, Hooper Foundation for Medical Research, San Francisco, California who reported that the complement-fixation test showed no increase in antibodies against psittacosis antigen. Ornithosis virus was isolated ${ }^{3}$ from the organs of 10 out of 35 pigeons captured at the school. However, no real connection between the

2 This work was carried out at the Rockefeller Influenza Laboratory, Division of Preventable Diseases, Minnesota Department of Health, under the direction of Dr. Carl Eklund.

- This work was carried out at the Rockefeller Influenza Laboratory, Division of Preventable Diseases, Minnesota Department of Health, under the direction of Dr. Carl Eklund. human disease and the pigeon virus could be established. The fact that this virus can ordinarily be isolated from throat washings of patients and established in mice suggests that the epidemic was not due to ornithosis. Also if the epidemic had been due to ornithosis, a higher proportion of severe cases would have been expected.

Recently, a group of workers (25) have described a virus which they isolated from cases of atypical pneumonia. Specimens of sera which have been saved from cases of the Kasson epidemic were submitted to Dr. Monroe D. Eaton for neutralization test with the new virus. $\mathrm{He}$ reports that specimens of the sera showed a significant rise in antibody titer as shown in Table VI. Paired serum specimens from 7 cases were tested. In $\mathbf{5}$ of these cases a 4 -fold increase in antibodies was demonstrated. In one case (P. S.) a 2-fold increase was found, and in the remaining case (J. B.) titers of both the acute-phase and convalescent serum specimens were above 64 , suggesting recent infection with the virus of atypical pneumonia. Most of these cases were among the "severe" cases of the epidemic but were not severe in comparison with the usual accounts of the

TABLE VI

Neutralization tests with the virus of atypical preumonia (strain De, amniotic passage)

\begin{tabular}{|c|c|c|c|c|c|c|c|c|c|c|c|}
\hline \multirow{2}{*}{ Patient } & \multirow{2}{*}{ Sex } & \multirow{2}{*}{ Age } & \multirow{2}{*}{$\begin{array}{l}\text { Date of } \\
\text { onset }\end{array}$} & \multirow{2}{*}{$\begin{array}{c}\text { Date of } \\
\text { specimen }\end{array}$} & \multicolumn{4}{|c|}{ Serum dilutions* } & \multirow{2}{*}{$\begin{array}{c}\text { Horse } \\
\text { serum } \\
\text { control** }\end{array}$} & \multirow{2}{*}{$\underset{\text { amniotic*** }}{\text { Normal }}$} & \multirow{2}{*}{$\begin{array}{c}\text { Test } \\
\text { animal }\end{array}$} \\
\hline & & & & & $1: 4$ & $1: 8$ & $1: 16$ & $1: 64$ & & & \\
\hline B. B. & $\mathbf{M}$ & $\begin{array}{c}\text { years } \\
11\end{array}$ & $10 / 8 / 42$ & $\begin{array}{l}10 / 10 / 42 \\
10 / 22 / 42\end{array}$ & $3 / 4$ & $\begin{array}{l}2 / 3 \\
0 / 3\end{array}$ & $0 / 3$ & & $5 / 7$ & $0 / 7$ & $\begin{array}{l}\text { C.R. } \dagger \\
\text { C.R. }\end{array}$ \\
\hline J. B. & F & 35 & $10 / 20 / 42$ & $\begin{array}{l}10 / 23 / 42 \\
11 / 17 / 42\end{array}$ & $\begin{array}{l}0 / 4 \\
0 / 4\end{array}$ & & $\begin{array}{l}0 / 4 \\
0 / 4\end{array}$ & $\begin{array}{l}0 / 4 \\
0 / 4\end{array}$ & $2 / 4$ & $0 / 4$ & $\begin{array}{l}\text { C.R. } \\
\text { C.R. }\end{array}$ \\
\hline D. $\mathbf{K}$. & $\mathbf{F}$ & 9 & $10 / 10 / 42$ & $\begin{array}{l}10 / 12 / 42 \\
11 / 3 / 42\end{array}$ & $\begin{array}{l}2 / 2 \\
0 / 3\end{array}$ & $2 / 3$ & $0 / 6$ & $0 / 3$ & $3 / 6$ & $0 / 3$ & $\begin{array}{l}\text { C.R. } \\
\text { C.R. }\end{array}$ \\
\hline J.A. & $\mathbf{M}$ & 14 & $10 / 7 / 42$ & $\begin{array}{l}10 / 10 / 42 \\
12 / 7 / 42\end{array}$ & $\begin{array}{l}3 / 4 \\
0 / 4\end{array}$ & & $0 / 4$ & & $3 / 4$ & $0 / 4$ & $\begin{array}{l}\text { C.R. } \\
\text { C.R. }\end{array}$ \\
\hline R. E. & $\mathbf{M}$ & 13 & $10 / 11 / 42$ & $\begin{array}{l}10 / 12 / 42 \\
11 / 3 / 42\end{array}$ & $\begin{array}{l}2 / 4 \\
0 / 4\end{array}$ & & $\begin{array}{l}2 / 3 \\
0 / 4\end{array}$ & & $2 / 4$ & $0 / 4$ & $\begin{array}{l}\text { C.R. } \\
\text { C.R. }\end{array}$ \\
\hline E. S. & $\mathbf{M}$ & 35 & $11 / 1 / 42$ & $\begin{array}{l}11 / 3 / 42 \\
11 / 17 / 42\end{array}$ & $\begin{array}{l}2 / 4 \\
0 / 4\end{array}$ & $0 / 4$ & $2 / 4$ & & 0 & 010 & $\begin{array}{l}\text { H. } \\
\text { H. }\end{array}$ \\
\hline P.S. & F & 11 & $10 / 11 / 42$ & $\begin{array}{l}10 / 12 / 42 \\
11 / 3 / 42\end{array}$ & $\begin{array}{l}4 / 4 \\
0 / 4\end{array}$ & $2 / 4$ & $4 / 4$ & & 100 & $0 / 0$ & $\begin{array}{l}\mathrm{H} . \\
\mathrm{H} .\end{array}$ \\
\hline J.W. & $\mathbf{M}$ & 10 & $10 / 6 / 42$ & $\begin{array}{l}10 / 10 / 42 \\
11 / 3 / 42\end{array}$ & $\begin{array}{l}3 / 4 \\
0 / 4\end{array}$ & & $0 / 4$ & & $3 / 4$ & $0 / 4$ & $\begin{array}{l}\mathrm{H} . \\
\mathrm{H} .\end{array}$ \\
\hline
\end{tabular}

* Numerator of fraction $=$ number of animals with pulmonary lesions; denominator $=$ number of animals tested. ** Control for virus activity.

*** Control for intercurrent respiratory infection in animals. 
disease. Although no sera from the extremely mild cases (those who were not in bed at all) were tested, it seems reasonable to assume from the clinical and temporal similarity of the cases that only one agent was involved in the outbreak.

\section{DISCUSSION}

The neutralization test thus indicates that the virus described by a group of investigators (25) was responsible for the Kasson epidemic. Further study of the virus should elucidate its relationship to that group of cases among the minor respiratory diseases characterized by a lingering cough.

Present evidence suggests that a disease entity is being established as a segment of the common respiratory diseases to take its place along side the common cold and influenza. As was pointed out as early as 1940 (1), the disease is probably not primarily a pneumonia, nor in view of the work accomplished (25) can it any longer be said that its etiology is unknown. The designation "atypical pneumonia" seems to exaggerate what is probably only an incident in the disease. Before this concept can be considered established, it will be necessary to isolate the virus from cases in which thorough clinical study excludes pneumonia, demonstrate its etiological relationship to the cases by neutralization test, and finally show its correspondence to virus isolated from cases with atypical pneumonia.

The author is grateful to Dr. Monroe D. Eaton, California State Department of Health, Dr. Carl Eklund, Minnesota State Department of Health, Dr. K. F. Meyer, Hooper Foundation, and Dr. F. R. Heilman, Rochester, Minnesota, for the work mentioned in the paper and for valuable advice and encouragement. Dr. D. E. Affeldt, Health Officer, Kasson, Minnesota, greatly assisted the field study of the outbreak, and Mr. I. J. Fox, Superintendent, Kasson Public Schools, gave excellent cooperation.

\section{BIBLIOGRAPHY}

1. Editorial, Virus studies in a new respiratory infection. J. A. M. A., 1940, 115, 2180.

2. Reimann, H. A., and Havens, W. P., An epidemic disease of the respiratory tract. Arch. Int. Med., 1940, 65, 138.

3. Dingle, J. H., et al, Primary atypical pneumonia, etiology unknown. War Med., 1943, 3, 223.

4. MacLeod, C. M., Primary atypical pneumonia. M. Clin. North America, 1943, 27, 670.
5. Reimann, H. A., Primary atypical pneumonias of unknown cause. J. Michigan M. Soc., 1944, 43, 147.

6. Commission on Acute Respiratory Diseases, Epidemiology of atypical pneumonia and acute respiratory disease at Fort Bragg, N. C. Am. J. Pub. Health, 1944, 34, 335.

7. Gallagher, J. R., Bronchopneumonia in adolescence. Yale J. Biol. and Med., 1934, 7, 23.

8. Bowen, A., Acute influenza pneumonitis. Am. J. Roentgenol., 1935, 34, 168.

9. Allen, N. H., Acute pneumonitis. Ann. Int. Med., 1936, 10, 441.

10. Reimann, H. A., An acute infection of the respiratory tract with atypical pneumonia. J. A. M. A., 1938, 111, 2377.

11. Miller, J. N., and Hayes, M. G., Bronchopneumonia of mild severity at the University of Oregon, Northwest. Med., 1939, 38, 12.

12. Maxfield, J. R., Atypical pneumonia with leukopenia. Texas State J. Med., 1939, 35, 340.

13. Kneeland, Y., Jr., and Smetana, H. F., Current bronchopneumonia of unusual character and undetermined etiology. Bull. Johns Hopkins Hosp., 1940, 67, 229.

14. Longcope, W. T., Bronchopneumonia of unknown etiology (variety X). Bull. Johns Hopkins Hosp., 1940, 67, 268.

15. Duggan, L. B., and Powers, W. L., Acute respiratory infection resembling so-called acute pneumonitis: 40 cases. U. S. Nav. M. Bull., 1942, 40, 651.

16. Moore, G. B., Jr., Tannenbaum, A. J, and Smaha, T. G., Atypical pneumonia in an army camp. War Med., 1942, 2, 615.

17. Gallagher, J. R., Acute pneumonitis; report of 87 cases among adolescents. Yale J. Biol. and Med., 1941, 13, 663.

18. Gallagher, J. R., Acute pneumonitis; report of epidemic. Yale J. Biol. and Med., 1941, 13, 769.

19. Iverson, H. A., An epidemic of acute respiratory disease associated with atypical pneumonia. Bull. Johns Hopkins Hosp., 1943, 72, 89.

20. Idstrom, L. G., and Rosenberg, B., Primary atypical pneumonia. Bull. U. S. Army M. Dept., 1944, 81, 88.

21. Meyer, K. F., Eddie, B., and Yanamura, H. Y., Ornithosis (psittacosis) in pigeons and its relation to human pneumonitis. Proc. Soc. Exper. Biol. and Med., 1942, 49, 609.

22. Dyer, R. E., Topping, N. H., and Bengtson, I. A., Institutional outbreak of pneumonitis identified as American " $Q$ " fever. Pub. Health Rep., 1940, 55, 1945.

23. Smadel, J., Green, R. H., Paltauf, R. M., and Gonzales, T. A., Lymphocytic choriomeningitis: two human fatalities following an unusual febrile illness. Proc. Soc. Exper. Biol. and Med., 1942, 49, 683.

24. Francis, T., Jr., Virus pneumonia. Canad. J. Pub. Health, 1944, 35, 49.

25. Eaton, M. D., Meiklejohn, G., and van Herick, W., Studies on the etiology of primary atypical pneumonia. J. Exper. Med., 1944, 79, 649. 